\title{
Pengembangan Media Shapes untuk Kreativitas Anak Usia Dini Kelompok B
}

\author{
Ermiani N. Kolta ${ }^{\text {a, } 1^{*}}$, Agus Sholeh ${ }^{\text {b, } 2}$, Rina Wijayanti ${ }^{\text {c, } 3}$ \\ ${ }^{\text {a }}$ SPS Anggrek Kota Batu, Indonesia \\ b,c Universitas Kanjuruhan Malang, Indonesia \\ ${ }^{1}$ colthaemyn@gmail.com*; ${ }^{2}$ Agussholeh@gmail.com; ${ }^{3}$ rinawijayantipsi@unikama.ac.id \\ *korespondensi penulis
}

\section{Informasi artikel \\ Received :}

August 26, 2018.

Revised :

September 08,2018.

Publish :

January 01, 2019.

Kata kunci:

Media Shapes

Kreativitas

\begin{abstract}
ABSTRAK kekurangan dari pengembangan media pembelajaran shapes untuk kreativitas anak usia dini. Penelitian ini menggunakan metode Research \& Development $(R \& D)$ menurut Borg dan Gall. Kelayakan produk didasarkan pada hasil penilaian ahli media, ahli materi, dan anak didik kelompok B Taman Kanak-Kanak (TK) sebagai subjek uji coba. Instrumen pengumpulan data menggunakan observasi, wawancara, angket, dan dokumentasi. Teknik analisis data berupa data kualitatif dan data kuantitatif. Hasil penelitian menunjukan bahwa media shapes yang telah dikembangkan melalui serangkaian uji coba serta validasi ahli dinyatakan layak. Hal ini didukung oleh penilaian ahli media dengan rata-rata skor 3,77 termasuk dalam kategori layak, penilaian ahli materi dengan rata-rata skor 3,6 termasuk kategori layak, uji coba lapangan utama mendapatkan presentase 98,55\% termasuk dalam kategori layak, dan uji coba lapangan operasional mendapatkan presentase $97,90 \%$ termasuk dalam kategori layak. Berdasarkan hasil penelitian yang telah dilakukan dapat disimpulkan bahwa media shapes untuk kreativitas anak usia dini kelompok B TK layak digunakan.
\end{abstract}

Keywords:

Media Shapes

Creativity

\begin{abstract}
Media Shapes Development for Early Childhood Creativity on Group B. This research aims to know forms, results, feasibility, advantages, disadvantages of learning media development shapes for early childhood creativity. This research uses research methods $(R \& D)$ according to the Borg and Gall. The feasibility of the product based on the results of the assessment of media experts, matter expert, and protege group B kindergarten as a test subject. Data collection instruments using observation, interview, question form, and documentation. The data analysis techniques in the form of qualitative data and quantitative data. The research results showed that the media shapes that have been developed through a series of trials and validation experts stated feasible. This is supported by the assessment of media experts with a 3,77 average score included in the categories viable, expert assessment of the material with an average score of 3,6 includes categories viable, the main field trials get percentage 98,55\% included in the category are worthy, the operational field trial and get a percentage of the 97,90\% included in the category. Based on the results of the research that has been done can be inferred that the media shapes for early childhood creativity group B kindergarten feasible.
\end{abstract}

Copyright $\odot 2019$ (Ermiani N. Kolta, Agus Sholeh, Rina Wijayanti). All Right Reserved

How to Cite: Kolta, E., Sholeh, A., \& Wijayanti, R. (2019). Pengembangan Media Shapes untuk Kreativitas Anak Usia Dini Kelompok B. Jurnal Inspirasi Pendidikan, 9(1), 60-65.

This work is licensed under a Creative Commons Attribution-ShareAlike 4.0 International License. Allows readers to read, download, copy, distribute, print, search, or link to the full texts of its articles and allow readers to use them for any other lawful purpose. The journal hold the copyright. 
Jurnal Inspirasi Pendidikan, VOL.9, NO.1, Edisi Januari 2019 Pengembangan Media Shapes untuk Kreativitas Anak Usia Dini Kelompok B Ermiani N. Kolta ${ }^{\text {a, }}{ }^{*}$, Agus Sholeh ${ }^{\text {b, } 2}$, Rina Wijayanti ${ }^{c, 3}$

\section{Pendahuluan}

Anak usia dini adalah kelompok usia yang belajar melalui pengalaman yang berada di sekitar mereka, dalam arti mereka mengamati, meniru, dan kemudian mengimplementasikan dalam sebuah pembelajaran, yang dapat terealisasikan atau dikembangkan jika anak-anak dibimbing dalam suatu lembaga pendidikan. Berdasarkan Peraturan Menteri Pendidikan dan Kebudayaan Republik Indonesia Nomor 137 Tahun 2014 tentang Standar Nasional Pendidikan Anak Bab 1, Pasal 1, Butir 10 yang menyatakan bahwa: Pendidikan anak usia dini adalah suatu upaya pembinaan yang ditujukan kepada anak sejak lahir sampai dengan usia enam tahun yang dilakukan melalui pemberian rangsangan pendidikan untuk membantu pertumbuhan dan perkembangan jasmani dan rohani agar anak memiliki kesiapan dalam memasuki pendidikan lebih lanjut. Usia dini merupakan masa dimana anak-anak akan mengalami proses perkembangan yang sangat pesat, termasuk didalamnya perkembangan kecerdasan, kreativitas, dan kemampuan emosi. Aspek perkembangan setiap anak mengalami perbedaan sesuai dengan karakteristiknya. Aspek-aspek perkembangan anak usia dini sesuai yang tercantum dalam Peraturan Menteri Pendidikan Nasional (Permen) Nomor 137 Tentang Standar Tingkat Pencapaian Perkembangan Anak Usia Dini meliputi nilai moral dan agama, fisik motorik, kognitif, bahasa, sosial emosional, serta seni. Salah satu aspek perkembangan yang sangat penting yang terdapat pada pembelajaran Pendidikan Anak Usia Dini (PAUD) adalah aspek seni (kreativitas). Menurut Suratno (2005) kreativitas merupakan bentuk aktivitas imajinatif yang mampu menghasilkan sesuatu yang bersifat asli atau original.

Pada anak usia dini, pengembangan kreativitas didapat dari pengalaman bermain yang menyenangkan didukung dengan lingkungan belajar yang diatur oleh guru yang terkait dengan dua hal yaitu metode dan media pembelajaran yang sesuai dengan anak usia dini. Media pembelajaran memiliki kedudukan yang sangat penting dalam mencapai tujuan pembelajaran secara efektif. Menurut Khadijah, (2016) media adalah segala sesuatu yang dapat digunakan untuk menyalurkan pesan dari pengirim pesan kepada penerima pesan sehingga dapat merangsang pikiran, perasaan, perhatian dan minat serta perhatian anak usia dini sedemikian rupa sehingga proses belajar terjadi. Sedangkan menurut association for education and communication technology (AECT) media didefinisikan sebagai segala bentuk yang dipergunakan untuk suatu proses penyaluran informasi (Dhini dkk, 2007). Menurut Slamet Suyanto (2005) peran media dalam pembelajaran khususnya dalam pendidikan anak usia dini semakin penting artinya mengingat perkembangan anak pada saat ini berada pada masa berfikir kongkret. Media pembelajaran yang dapat digunakan oleh guru untuk membantu anak dalam mengembangkan kreativitasnya dapat berupa media pembelajaran yang sering ditemui di sekolah, salah satunya adalah shapes.

Menurut kamus Inggris-Indonesia yang disusun oleh John M. Echols dan Hassan Shadily, shape merupakan kata dasar dari shapes yang artinya bentuk. Shapes yang dimaksudkan dalam penelitian ini adalah shapes yang merujuk pada bentuk geometri. Pada umumnya, shapes dikenal sebagai salah satu pengetahuan yang ada di pembelajaran matematika. Penggunaan shapes dalam pembelajaran matematika ini sudah sangat sering digunakan di berbagai tingkatan pendidikan, termasuk pada tingkat PAUD itu sendiri hanya, pada tingkat PAUD penggunaan shapes lebih dikenalkan pada bentuk geometrinya. Dikutip dalam ilmu bahasa inggris "Shapes is a fun educational activity to help children learn basic properties of simple geometric figures". Yang artinya: Bentuk adalah kegiatan pendidikan yang menyenangkan untuk membantu anak-anak mempelajari properti dari bentuk-bentuk dasar geometri. Menurut Jackman (2012) geometri adalah area matematika yang melibatkan bentuk, ukuran, ruang, posisi, arah dan gerakan yang menggambarkan serta mengklasifikasikan dunia fisik yang ada di sekitar kita. Berdasarkan kutipan di atas, dapat dilihat bahwa, pengunaan shapes yang hanya mengenalkan bentuk-bentuk dasar geometri pada anak usia dini sudah menjadi suatu kegiatan pendidikan yang menyenangkan bagi mereka. Hal ini akan lebih menyenangkan lagi jika shapes bukan hanya digunakan untuk pembelajaran matematika, tetapi bisa digunakan juga untuk mengasah kreativitas pada anak usia dini. Maka dari itu peneliti tertarik dan bermaksud untuk mengembangkan media pembelajaran yang berasal dari shapes yang akan digunakan oleh anak usia dini khusus pada kelompok B Taman Kanak-Kanak (TK) untuk mengembangkan kemampuan kreativitasnya. Selain itu, peneliti juga berharap aspek-aspek perkembangan anak yang 
Jurnal Inspirasi Pendidikan, VOL.9, NO.1, Edisi Januari 2019 Pengembangan Media Shapes untuk Kreativitas Anak Usia Dini Kelompok B Ermiani N. Kolta ${ }^{\text {a, }}{ }^{*}$, Agus Sholeh ${ }^{\text {b, } 2}$, Rina Wijayanti ${ }^{c, 3}$ Hal: $60-65$ lainnya seperti kognitif, sosial emosional, bahasa, fisik motorik, nilai agama dan moral anak dapat berkembang melalui media pembelajaran ini.

\section{Metode}

Jenis penelitian ini adalah Research and Development $(R \& D)$ atau penelitian dan pengembangan dengan mengacu pada model pengembangan menurut Borg \& Gall. Prosedur pengembangan media shapes dalam penelitian ini dilakukan melalui delapan tahap yakni: penelitian dan pengumpulan informasi awal, perencanaan, pengembangan format produk awal, uji coba awal, revisi produk utama, uji coba lapangan utama, revisi produk akhir, dan uji coba lapangan operasional. Desain ujicoba media shapes melalui uji coba awal yang dilakukan oleh validator yakni 1 orang ahli media dan 1 orang ahli materi untuk menentukan apakah media shapes sudah layak digunakan sebagai media pembelajaran untuk anak Taman Kanak-Kanak (TK) Kelompok B, ujicoba lapangan utama dengan 4 anak kelompok B TK yang memiliki kemampuan dibawah sedang, sedang, dan diatas sedang, serta 14 anak kelompok B TK untuk uji coba lapangan operasional. Instrumen pengumpulan data yang digunakan dalam penelitian pengembangan ini adalah pedoman wawancara, angket berupa instrumen checklist, dan lembar observasi serta dokumentasi. Teknik analisis dalam penelitian ini menggunakan teknik deskriptif kuantitatif, yang berupa pernyataan sangat baik, baik, cukup baik, kurang dan sangat kurang yang diubah menjadi data kuantitatif dengan skor 0-4 atau skala 5. Skor rata-rata yang diperoleh didapat dengan cara jumlah skor dibagi dengan jumlah responden atau item. Setelah penyajian data dalam bentuk rata-rata skor, langkah selanjutnya adalah mendeskripsikan dan mengambil kesimpulan tentang masing-masing indikator melalui konversi data. Adapun acuan yang digunakan adalah sebagai berikut:

Tabel 1. Konversi Data

\begin{tabular}{|l|l|}
\hline Perhitungan & Kriteria \\
\hline $\mathbf{X}>3,2$ & Sangat Baik \\
\hline $2,4<\mathbf{X} \leq 3,2$ & Baik \\
\hline $1,6<\mathbf{X} \leq 2,4$ & Cukup \\
\hline $0,8<\mathbf{X} \leq 1,6$ & Kurang \\
\hline $\mathbf{X} \leq 0,8$ & Sangat Kurang \\
\hline
\end{tabular}

\section{Hasil dan pembahasan}

Produk yang dikembangkan dalam penelitian ini adalah media pembelajaran yang dinamakan media shapes. Media shapes merupakan suatu media yang dikembangkan yang merunjuk pada bentuk geometri seperti bentuk persegi panjang, bentuk segitiga, bentuk segi empat, bentuk oval, bentuk bintang, bentuk lingkaran, bentuk hati, bentuk bulan sabit, dan bentuk ketupat. Media shapes adalah media yang dikhususkan untuk mengembangkan kreativitas anak kelompok B Taman Kanak-Kanak (TK) dengan cara penggunaannya yakni, menyusun beberapa bentuk shapes yang ada menjadi suatu hasil karya yang orginal dari setiap anak yang disesuaikan dengan tema yang diberikan pada penelitian ini. Melalui media pembelajaran yang dikembangkan, diharapkan mampu mengoptimalkan proses pembelajaran, mengasah kemampuan anak usia dini, dan dapat menciptakan suasana belajar yang menyenangkan.

Media shapes dikembangkan dengan maksud untuk dapat mengasah ke-6 aspek perkembangan anak yang salah satu aspek utamanya adalah seni atau kreativitas dan 5 aspek lainnya yakni kognitif, bahasa, fisik motorik, sosial emosional, serta nilai agama dan moral yang dikemas dalam suatu pembelajaran menggunakan media yang menarik, sederhana, sesuai dengan pengalaman anak, serta menyenangkan. Media shapes telah memenuhi syarat dalam pengembangan media pembelajaran yang layak menurut Nana Sudjana (1990) yaitu ketepatan dengan tujuan pembelajaran, mendukung terhadap isi bahan pembelajaran, ketersediaan waktu untuk menggunakannya, serta sesuai dengan taraf berpikir anak. Tujuan penelitian pengembangan ini adalah menghasilkan media shapes yang layak digunakan dalam proses pembelajaran.

Uji kelayakan produk dalam penelitian pengembangan ini dilakukan melalui beberapa tahap uji coba untuk mendapatkan saran, sehingga media shapes yang dikembangkan layak digunakan 
Jurnal Inspirasi Pendidikan, VOL.9, NO.1, Edisi Januari 2019 Pengembangan Media Shapes untuk Kreativitas Anak Usia Dini Kelompok B Ermiani N. Kolta ${ }^{\text {a, }}{ }^{*}$, Agus Sholeh ${ }^{\text {b, } 2}$, Rina Wijayanti ${ }^{\text {c, } 3}$

Hal: 60-65

dalam pembelajaran dengan mencangkup semua tema khususnya tema "tanaman" yang menjadi tema yang diujicobakan dalam penelitian pengembangan ini. Tahapan dalam penelitian ini meliputi: 1) Tahap validasi melalui uji coba awal yang dilakukan oleh ahli media dan ahli materi dengan hasil perolehan skor dari ahli media sebesar 3,77 dari skor maksimal 4,00 dan berkategori "sangat baik"; serta ahli materi dengan jumlah skor 3,6 dari skor maksimal 4,00 dan berkategori "Sangat Baik". 2) Uji coba lapangan utama,dengan menggunakan 13 indikator penilaian yang melibatkan 4 orang anak dengan kemampuan dibawah sedang, sedang, dan diatas sedang, mendapatkan presentase 98,55\% yang termasuk dalam kategori "Layak" atau "Sangat Baik".3) Uji coba lapangan operasional, melibatkan satu kelas kelompok B TK yang berjumlah 11 anak dengan presentase 97,90\% yang termasuk dalam kategori "Layak" atau "Sangat Baik". Untuk lebih jelasnya dapat dilihat pada gambar 1 di bawah ini.

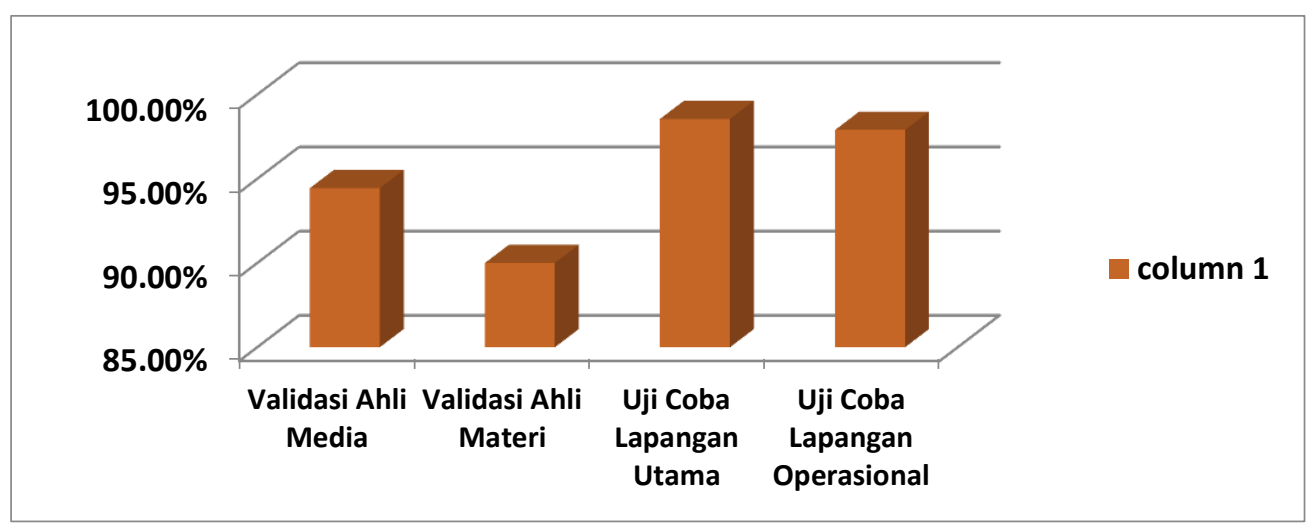

\section{Gambar 1. Perolehan Skor Hasil Uji Coba Awal, Uji Coba Lapangan Utama, Uji coba Lapangan} Operasional

Dari hasil pengamatan pada uji coba lapangan awal dan uji coba lapangan operasional, respon anak kelompok B TK umumnya sangat suka, antusias, dan tertarik dalam membuat bentuk dari media shapes. Hal ini terlihat dari aktivitas yang dilakukan oleh tujuh orang anak yang ingin mencoba membuat beberapa bentuk berbeda dari tema yang digunakan dalam penelitian ini, seperti: 1) Membuat mobil, pesawat, truck yang notabene masuk dalam tema kendaraan; 2) Membuat orang yang masuk dalam tema diriku; 3) Membuat pak tani yang masuk dalam tema keluargaku (profesi); 4) Membuat rumah, kamar, rumah warna warni yang masuk dalam tema lingkungan; 5) membuat benda langit seperti bulan, bintang, matahari, suasana malam, dan suasana siang yang masuk dalam tema alam semesta; 6) membuat princess, lingkaran, kotak dan hiasan yang masuk dalam kegiatan imajinasi lainnya dari anak. Secara umum tanggapan anak usia dini kelompok B TK sebagai pengguna media shapes, yaitu mereka tertarik terhadap media pembelajaran tersebut dan sangat menyukai kegiatan pembelajaran dengan menggunakan media shapes. Hal ini diketahui dari hasil pengamatan selama kegiatan yakni setelah anak-anak membuat hasil karyanya dan menunjukan pada teman maupun peneliti, mereka selalu membongar kembali dan membuat ulang dengan bentuk yang berbeda-beda kurang lebih 4 sampai 6 kali. Bahkan ketika diminta bermain pada sudut pengaman sebagian anak tidak ingin melakukannya, mereka lebih memilih untuk bermain dengan media shapes sampai mereka merasa cukup dalam membuat hasil karyanya. Seperti yang dikemukakan oleh Ahmad Rohani (1997) bahwa manfaat pemilihan media adalah meningkatkan daya tarik serta perhatian siswa.

Berdasarkan penilaian yang telah didapatkan melalui proses uji coba awal, uji coba lapangan utama, dan uji coba lapangan operasional menunjukan bahwa media shapes layak digunakan sebagai media pembelajaran untuk kreativitas pada anak kelompok B TK dengan mencangkup semua tema yang salah satu temanya adalah tema "Tanaman" yang digunakan dalam penelitian ini. 
Jurnal Inspirasi Pendidikan, VOL.9, NO.1, Edisi Januari 2019 Pengembangan Media Shapes untuk Kreativitas Anak Usia Dini Kelompok B Ermiani N. Kolta ${ }^{\text {a, }}{ }^{*}$, Agus Sholeh ${ }^{\text {b, } 2}$, Rina Wijayanti ${ }^{c, 3}$

\section{Simpulan}

Berdasarkan penelitian yang telah dilakukan diperoleh kesimpulan bahwa, anak usia dini kelompok B TK sangat kreatif dengan menunjukan kreativitasnya dalam menyusun berbagai macam bentuk shapes seperti: bentuk persegi panjang, bentuk segitiga, bentuk segi empat, bentuk oval, bentuk bintang, bentuk lingkaran, bentuk hati, bentuk bulan sabit, dan bentuk ketupat dapat dibuat menjadi bentuk bunga mawar, bunga matahari, bunga melati, bunga teratai, pohon, pohon cemara, dan rumput yang masuk dalam tema "tanaman". Bentuk mobil, pesawat, truck yang masuk dalam tema "kendaraan". Bentuk orang yang masuk dalam tema "diriku". Bentuk pak tani yang masuk dalam tema "profesi". Bentuk rumah, kamar, rumah warna warni yang masuk dalam tema "lingkungan". Bentuk benda langit seperti bulan, bintang, matahari, suasana malam, dan suasana siang yang masuk dalam tema "alam semesta". Serta bentuk princess, lingkaran, kotak dan hiasan yang masuk dalam kegiatan imajinasi lainnya dari anak. Hasil uji coba awal yang dilakukan oleh ahli media dan ahli materi, uji coba lapangan utama serta uji coba lapangan operasional semuanya mendapatkan hasil yang "Sangat Baik" sehingga media shapes untuk kreativitas anak usia dini kelompok B dapat dinyatakan "Layak" untuk digunakan dalam pembelajaran. Media shapes untuk kreativitas anak usia dini memiliki kelebihan dari segi bentuk, ukuran, kemenarikan, serta mampu merangsang ke-6 aspek perkembangan anak yang salah satu aspeknya adalah aspek seni atau kreativitas.

\section{Saran}

Berdasarkan hasil penelitian yang telah dilakukan, maka ada beberapa saran yang akan disampaikan sebagai berikut: 1) bagi peneliti atau pengembang selanjutnya, diharapkan dapat lebih menyempurnakan media pembelajaran yang telah dikembangkan serta lebih inovatif lagi dalam menciptakan media pembelajaran yang bermanfaat bagi anak usia dini dalam proses pembelajaran, 2) bagi tenaga pengajar/guru, diharapkan dapat memanfaatkan media shapes sebagai salah satu alternatif media pembelajaran sehingga proses pembelajaran di kelas lebih menyenangkan bagi anak usia dini, 3) bagi anak usia dini kelompok B, diharapkan media shapes dapat dimanfaatkan untuk kegiatan pembelajaran yang menyenangkan karena mereka dapat bermain sambil belajar.

\section{Referensi}

Ambarita, M. H. 2015. Pengembangan Multimedia Pembelajaran Interaktif Materi Berhitung untuk Anak Kelompok A TK Teruna Bangsa. Yogyakarta: PPs UNY.

Depdiknas. 2015. Permendiknas Nomor 137 Tahun 2014 Tentang Kurikulum 2013 Pendidikan Anak Usia Dini. Jakarta: Depdiknas.

Dewi, K. 2017. Pentingnya Media Pembelajaran untuk Anak Usia Dini. Palembang: PPS UIN Raden Fatah Palembang.

Echols, M. J., Shadily, H. 1976. Kamus Inggris - Indonesia. Jakarta: PT Gramedia Pustaka Utama.

Hartati, S. 2017. Penyelenggaran Program PAUD. Jurnal Ilmiah Visi PGTK PAUD dan DIKMAS, 12 (2): $155-162$.

Novelandari, I. 2016. Meningkatkan Kemampuan Mengenal Bentuk Geometri Melalui Kegiatan Mozaik pada Kelompok A. Surabaya: PPS UNS.

Pusat Kurikulum Balitbang 2007. Standar Isi Pendidikan Anak Usia Dini. Jakarta: Depdiknas.

Retnaningsih, I. 2017. Pengembangan Media Kartu Kuartet untuk Mengembangkan Kosakata pada Anak Kelompok B Taman Kanak-Kanak. Jurnal Ilmu Pendidikan, 6 (1): 300-306.

Sit, M., Khadijah, Nasution, F., Wahyuni, S., Rohani, Nurhayani, Sitorus, S.A., Armayanti, R., Lubis, Z.H. 2016. Pengembangan Kreativitas Anak Usia Dini. Medan: Perdana Publishing.

Syarah, M. 2017. Pengelolaan Media Pembelajaran Anak Usia Dini di TK Sambinoe Takengon Aceh Tengah. Banda Aceh: PPs UIN.

Taiyeb H. 2016. Model Permainan Kreativitas Anak Usia Dini. Makassar: PPs UNM.

Team, B. (bigbanktheories@gmail.com). 17 Desember 2016. Pengertian dan Penggunaan Shapes. 
Jurnal Inspirasi Pendidikan, VOL.9, NO.1, Edisi Januari 2019 Pengembangan Media Shapes untuk Kreativitas Anak Usia Dini Kelompok B Ermiani N. Kolta ${ }^{\text {a, }}{ }^{*}$, Agus Sholeh ${ }^{\text {b, } 2}$, Rina Wijayanti ${ }^{c, 3}$ Hal: $60-65$

Wati, R. 2016. Peningkatan Kemampuan Mengenal bentuk Geometri Melalui Permainan Dadu Geometri pada Siswa Kelompok B Anak Raudhatul Athfal Mluweh. Salatiga: PPs USKW.

Yafie, E., Iriyanto, T., Gonandi, L., Wahyudi, S. 2018. Workshop Pembuatan Media Education Berbasis PPT Anak Usia Dini untuk Guru Se-kota Malang dan Alumni PG-PAUD Universitas Negri Malang. Jurnal Karinov, 1 (2): 1-8.

Zaman, B., Eliyawati C. 2010. Media Pembelajaran Anak Usia Dini. Depok: Fakultas Ilmu Pendidikan Universitas Pendidikan Indonesia. 